nation of the aperture apparently round and even, but this portion has been cut out of the matrix.

Relations and Distribution. - Induced probably by the character of the aperture in Phillips' figure, Mr. Leckenby referred this species to "Acteon glaber," erroneously as I cannot help thinking. No doubt the cylindro-conical outline of the shell, the tabulation of the bodywhorl, and the flatness of its sides, are strong points of resemblance; but the proportions are different, to say nothing of other features, which a bad state of preservation, especially with regard to the termination of the aperture, renders somewhat difficult to describe.

Three specimens are known to me from the Scarborough Limestone, and there is a very stout variety, apparently belonging to this species, in Mr. Leckenby's Cornbrash collection. The rectangular outline of the whorls and stumpy spire serve to separate it from Act. Scarburgensis.

\title{
EXPLANATION OF PLATE $\nabla$.
}

Figs. 1, 1a. Actaonina humeralis, Phillips. Dogger, Peak. York Museum (shell partially preserved). Back and front. $\times 2$.

"2. Acteomina sp. Dogger, Peak. Bean Collection, British Museum. Back. $\times 2$.

" 3. Actconina htoneralis, Phil. Dogger, Peak. York Museum (specimen showing the striæ). Back. $\times 2$.

, 4. Aetcon Sedyviei, Phillips. Dogger, Peak. Bean Collection, British Museum. Back. $\times 2$.

"5. Actreon pullus, Morris and Lycett (var. of Ac. Sed $\quad$ vici). Millepore Rock of the coast. Bean Collection, British Museum. Front. $\times 2$.

" 6 and 6a. Actaonina glabra, Phillips. Millepore Rock of the coast. Bean Collection, British Museum. Back and front. $\times 2$.

"7. Actronina tumidula, Morris and Lycett. Scarborough Limestone, White Nab. Bean Collection, British Museum. TYPE REFIGURED. Front. $\times 2$.

" 8, 8a. Acteonina cinerea, sp. n. Scarborough Limestone, Cloughton Wyke. Leckenby Collection. Back and front. Nat. size.

" 9, 9a. Actaomina Scarburgensis. Lycett (var. approaching Act. grgantea, Desl.). Cornbrash, Scarborough. My Collection. Back and front. Nat. size.

"10,10a. Bulla undutata, Bean. Cornbrash, Scarborough. Leckenby Collection. Back and front. Nat. size.

", 11, 11a. " Troohus" jugnosus, Bean MS. Dogger, Peak. Bean Collection, British Museum. Nat. size, and portion enlarged.

(To be concluded in our next Number.)

III.-On the Presence of Syentte and Gabbro in Essex County, Massachusetts.

By Dr. M. E. Wadsworth.

Syenite. - Much of the eastern coast of Essex County, Massachusetts, extending from Salem to a point beyond West Manchester, has been found by the writer to be occupied by a typical syenite of a reddish and greyish colour, which in its macroscopic characters appears to be identical with that from Planen'schen Grund, Saxony. The syenite in places contains much biotite, and also, near West Manchester, quartz grains (segregations?). This syenite is often cut by dykes of a fine-grained greyish syenite, which holds the same relation to the syenite proper as the micro-granite dykes do to the granite of the 
region, and hence, for convenience of description, the rock of the syenite dykes may be styled micro-syenite.

The relation of the syenite proper to the common hornblendic and lepidomelane granite ${ }^{1}$ of the region (the syenite of Hitchcock, and other American authors) lias not yet been made out distinctly. Both are eruptive, and heretofore have been taken to form the same rock-mass. In fact, the syenite is partly in the areas mapped as belonging to the Norian or "Naugue Head" formation, and partly in that mapped as belonging to the Huronian. Near West Manchester the granite rises obliquely in a dome-shaped mass from beneath the syenite, but the actual contact was not seen; and elsewhere, when the two rocks were in juxtaposition, good contacts were not found. The difficulty in determining their relations was further increased by their close resemblance to each other macroscopically, and the fact that the micro-granite and micro-syenite dykes, by which the granite and syenite are respectively cut, are closely alike. So far as seen, the granite occupies the coast northward from near "Manchester-by-the-Sea," and the interior of the country going southward from that point. At least, an examination of all the railway cuttings between Manchester and Salem revealed syenite at only two of them, and those were near the sea-shore. The syenite, however, occupies a large portion of the coast-line between Manchester and Salem. The preponderance of evidence is that the granite is the younger rock, unless it is contemporaneous with the syenite.

Gabbro.-On Woodbury's Point, Beverley, occurs a gneissoid schist which is probably the oldest rock in the vicinity. This is cut by irregular dykes of gabbro which generally run approximately parallel to the foliation of the schist. This gabbro varies much in structure in different portions even in the same dyke, three different types being found with various intermediate grades. 1. A compact, tough, milk-white or waxy felspathic mass, containing a few grains of diallage, and closely resembling many specimens of the Volpersdorf gabbro. 2. A crystalline rock composed of approximately equal amounts of felspar and diallage, and in structure is like a coarsely crystalline diabase, or the common crystalline gabbros like those from Raduthal and Neurode. 3. A rock in which the felspar becomes subordinate, serving merely as a matrix to hold the large porphyritic crystals of diallage, some of which are two or three inches long. From the alterations observed by the writer in the gabbros from this place, San Domingo, and other localities, he has been led to believe that many of the coarsely crystalline diorites of these regions have been formed from the alteration of gabbro, in which the diallage has been replaced by secondary hornblende. The before-mentioned syenite was found cutting the gabbro and holding fragments of it, while the micro-syenite contains diallage fragments at the places in which it traverses the gabbro.

In the granite of Davis Neck, Bay View, Gloucester, a variety of gabbro occurs quite abundantly. This is a grey, coarsely crystalline rock, with predominating felspar. The felspar is in approximately

1 Proc. Boston Soc. Nat. Hist. 1878, rol. xix. pp. 309-316. 


\section{Dr.Mr.E.Wadsurth-Syenite and Gabbro in Massachusetts. 209}

square prisms, weathering grey, but often on the fresh fracture having a bluish or pinkish tinge. In many parts this gabbro contains crystals and masses of a pinkish striated felspar (probably labradorite), one piece of which was fifteen inches long by seven inches broad. The gabbro occurs in rounded crater or neck-like masses, and in dykes, one of which is twenty-seven feet in width. The largest gabbro area holds in its centre a pinkish mass composed mainly of the pinkish felspar before mentioned. This mass is nearly round in outline, and from fourteen to fifteen feet in diameter, while it apparently widens in depth. This eruptive gabbro is like much of that which has been regarded as typical of the so-called Norian formation, and apparently to a boulder of it found on Marblehead Neck is due the first suggestion of the presence of the Norian formation in Eastern Massachusetts. Bonlders both of the Davis Neck and Woodbury Point gabbros have been observed by the writer freely scattered in the drift over Middlesex and Essex Counties, and therefore these rocks doubtless exist in sitú in many other localities than the two mentioned.

Elaolite (Zircon) Syenite.-The writer bas previously pointed out ${ }^{1}$ the existence in Marblehead of a zircon syenite like that from Fredericksvæm, Norway. The same rock further occurs in Salem, particularly on Salem Neck, where it forms dykes and large masses in the diabase. It was here that sodalite and elæolite were found in an apparent boulder many years ago, and the writer has discovered that the coarser crystalline portions of the zircon syenite contain elæolite in quite large and abundant masses, giving rise to the rock known as elæolite syenite. The zircon syenite is further found on the Beverley shore.

Dykes. - The entire coast-line is more or less cut by dykes of microgranite, micro-syenite, quartz-porphyry, diabase, diorite, and melaphyre. Part of the diabase and melaphyre dykes are non-porphyritic on the sides, but in the intermediate portions they are filled with felspar crystals, varying from minute ones to giant forms six to eight. inches in length. Many of these crystals are of irregular outline, and have been penetrated by the ground-mass.

Trachyte.-A dyke of trachyte of the same kind as that previously described by the writer ${ }^{2}$ as forming an overflow on Marblehead Neck, was found on the Beverley shore, near the Manchester boundary-line. This dyke cuts the granite, both walls being found, and at the point observed it was forty-four inches wide.

Geological Succession.-If the sequence of all the dykes cutting one another be taken, numerous epochs of eruption can be found, but speaking broadly the general order of arrangement would, from the present evidence, appear to be as follows :-

1. The schistose rocks which seem to form the basis, and to be of sedimentary origin. 2. The older basaltic rocks-gabbro, diabase, and diorite-which have been intruded through the schist and occupy large areas of the country. 3. Syenite. 4. Elæolite (zircon) syenite.

1 Proc. Boston Soc. Nat. Hist. Feb. 1, 1882.

2 Proc. Boston Soc. Nat. Hist. 1881, vol. xxi. pp. 288-294.

DECADE III., 一 VOL. II. -NO. V. 
5. Granite. 6. Felsite. 7. The later basaltic rocks-diabase and melaphyre. 8. Trachyte.

The above is given as the results of field observations in the summer of 1883 , the specimens not having been unpacked since collected. It is intended to make a microscopic examination of the rocks at the earliest time my duties will permit, and to publish the results with further details of the field relations.

\section{IV.-On a Possible Cause of the Disturbance of Magnetic Compass-Nemdles during Earthquakes. \\ By Charles Datison, B.A., Mathematical Master at King Edward's School, Birmingham.}

TROM time to time, during earthquake-shocks, magnetic compassneedles within the disturbed areas have been seen suddenly deflected from their position of rest, returning to it shortly, after one or more oscillations. This movement admits of two very different interpretations. Either it may be attributed to an intimate connexion between earthquakes and terrestrial magnetism, or it may be regarded as merely a consequence of the shock of the earthquake. 'The object of this note is to point out a possible mechanical cause, and to guard, therefore, against a too hasty assumption of a maynetic origin for these disturbances.

The following examples may be given to illustrate the nature of these movements :

(1.) On August 28, 1787, an earthquake was felt at Stuttgart, Munich, Augsburg, Landshut. Innspruck, Pappenheim, Ansbach, Empten, Dillingen, Ratisbon, Zurich, and Bâle. At Innspruck, the direction of the shock was from S.W. to N.E. A magnetic needle at the same place deviated $0^{\circ} 12^{\prime}$ to the east. ${ }^{1}$ Here, then, the south end of the needle moved in the direction opposite to that of the earthquake-shock.

(2.) On December 2, 1841, an earthquake was felt at the following places :-At St. Rambert-en-Bugey at 7.47 P.M.; Lyons at 7.50 ; Geneva and Chambéry at 7.53 ; Chessy, Anse, and in the neighbourhood of Berne at 8 ; and at Lons-le-Saulnier at 8.15, and again at 8.30. At Billey the direction of the shock was said to be from $N$. to S.; at Geneva from S.W. to N.E. ; and at St. Rambert-en-Bugey, apparently from E. to W. From the recorded times and directions, it follows that the focus of the earthquake must have lain to the east of the meridian of Lyons. At this town a compass-needle suddenly turned from N. to N.N.W. ${ }^{2}$ Here again, then, the south end of the needle moved in the opposite direction to that of the shock.

(3.) On February 20, 1835, occurred the great earthquake of Concepcion, described by Fitzroy, Caldcleugh, Darwin, and others. There is some uncertainty as to the direction of the shock, but the balance of the evidence is in favour of the seismic focus having been

1 R. Mallet, Catalogue of recorded Earthquakes, Brit. Assoc. Rep. 1854, p. 18.

2 Ibid. p. 314. 